\title{
Menacing or Mimicking? Realities of Youth Gangs
}

BY JAMES C. HOWELL

\section{A B S T R A C T}

\section{N T R O D U C T I O N}

For the past several decades, youth gangs $^{1}$ have played a prominent role in urban youth culture-feared by citizens, admired and emulated by many young people, and followed closely by the media. Although youth gangs have an extended presence in the United States (Howell, 1998), they remain largely an enigma in public perceptions. No two gangs are alike and no two communities' gang problems have the same dimensions; this variance frustrates the media and others, who find it more convenient to simplify gangs with broad-brush descriptions (Esbensen \& Tusinski, 2007).

Research suggests that cities, towns, and rural counties can be grouped into three categories with respect to their experience with youth gangs. The overwhelming majority of these localities are in the first category: Either they have never experienced a youth gang problem or, if they have, it is not a persistent problem that endangers residents' safety (Howell \& Egley, 2005a). These communities tend to be rural areas and small towns with populations under 25,000. The second group of communities-cities and suburbs with populations between 25,000 and 100,000 -are the most difficult to classify with certainty, because many of them will experience a youth gang problem at some point, but it may not

\section{Menacing or Mimicking?}

Without close scrutiny, it is often difficult to assess the dangerousness of the typical youth gang in less populated areas. Two sources in particular have a tendency to misrepresent the characteristics and activities of youth gangs: the gangs themselves and the media. ${ }^{2}$ These are common sources of popular images of youth gangs in the United States. However, most youth gangs are not as formidable as these sources would have us believe. ${ }^{3}$

Felson (2006) offers an insight that calls into question several popular perceptions of youth gangs. He argues that the gangs themselves create myths ${ }^{4}$ as part of what he calls their "Big Gang Theory." The process often transpires as follows: Youths sometimes feel that they need protection on the streets in their communities; the gang provides this service; however, few gangs are nasty enough to be particularly effective in protecting youths; hence they need to appear more dangerous than they actually are to provide maximum protection.

James C. Howell, Ph.D., is a Senior Research Associate with the National Youth Gang Center, Tallahassee, Florida. The research on which this article is based was conducted under Grant \#95-JD-MU-K001, awarded to the Institute for Intergovernmental Research, NYGC, from the Office of Juvenile Justice and Delinquency Prevention. Points of view or opinions expressed herein are those of the author and do not necessarily represent the official position or policies of the NYGC or its funding agencies. 
Felson observed that gangs use a ploy found in nature to maximize the protection they seek to provide. In order to scare off threatening predators, some harmless animals and insects will mimic a more dangerous member of their species. In turn, predators learn to avoid all species-both harmless and dangerous-that look alike. For example, Felson notes that the coral snake, an extremely dangerous viper, is mimicked by the scarlet king snake, which is often called the "false coral snake" because of its similar colors and patterns. Although the latter snake is not venomous, its threatening appearance scares off potential predators.

Felson suggests that gangs use the same strategyproviding signals for local gang members to make their gangs resemble truly dangerous big-city gangs. These standardized signals or symbols typically consist of hand signs, colors, graffiti, clothes, and language. By displaying gang signals and employing a famous gang name, gang members can create a more menacing image. Once enough people believe their overblown dangerous image, it becomes accepted as reality. Unfortunately, the media sometimes unwittingly help local gangs promote their Big Gang Theory. For example, when television stations broadcast that local groups claim to be gangssuch as Crips or Bloods that have a legendary image as Los Angeles gangs-the broadcast helps validate scary images of the local gangs.

Misrepresentations of gangs in the print media have been well documented over the past quarter century (Esbensen \& Tusinski, 2007). As Esbensen and his colleague discovered, leading newsweeklies consider "gangs" to be a monolithic phenomenon and often do not distinguish among different types of gangs, such as prison gangs, drug gangs, and youth gangs. Second, the media perpetuate the myth that gang members are exclusively male and made up of racial or ethnic minorities. Third, they portray gangs as an urban problem that has spread to new areas, as part of a conspiracy to establish satellite sets across the country. Fourth, most gangs are characterized as hierarchical organizations with established leaders and operating rules. Fifth, the pervasiveness of violence is exaggerated.Although gang coverage by broadcast media has not been exhaustively analyzed, it appears that the gang phenomenon is exaggerated and misrepresented in a manner similar to the media distortions of the crack cocaine "epidemic" of the late 1980 s and early 1990 s (see Reeves \& Campbell, 1994, for an exhaustive analysis of that coverage). Reeves and Campbell's landmark study revealed that the public was misled in the so-called crack cocaine "epidemic," principally in television news coverage, into believing that use of this drug was extremely widespread. The ensuing anti-drug campaign preached that crack cocaine use indicated pervasive moral decay across the country. Government resources and public priorities were diverted from addressing underlying causes of drug use to blaming minority transgressors whom the anti-drug laws targeted for immoral tendencies and punishing them severely.

Similarly, broadcast media tend to sensationalize the youth gang phenomenon. Almost invariably, newspaper accounts, popular magazine articles, and electronic media broadcasts on youth gangs contain at least one myth or fallacy.

There are a number of derivative myths from the "Big Gang Theory" that apply principally to communities without entrenched gang problems. Stakeholders (public officials, agency heads, and key professionals such as judges, probation officers, and the like) in these communities often are susceptible to misleading information about youth gangs, and frequently feel uncertain regarding what an appropriate response might be. Prevention and control efforts are far more likely to be effective if they match the level of gang problem that actually exists.

\section{Consideration of Key Myths About Gangs}

\section{The Formal-Organization Myth}

The Big Gang Theory that imprisoned California Crips and Bloods gang members relayed in interviews to susceptible researchers in the late 1980s (Skolnick, 1989, 1990 ) is a prime example of Felson's (2006) observation that gangs can grossly exaggerate their nastiness. The gang members said they were transforming themselves into formal criminal organizations to profit from the "crack cocaine epidemic." 5 They also claimed they were expanding their criminal operations across the country. Klein (1995, pp.40-43, 112-135) provides an excellent critique of Skolnick's reports from the interviews.

The California gang members' stories influenced public perceptions of gangs via broadcast media in several ways. The myth of formal organization, 
that gangs were becoming large, powerful criminal organizations-much like highly structured corporations-became widely accepted. This feature of the Big Gang Theory was also promoted at every level of government, including the United States Congress and in the executive branch of the federal government (Howell, 2003, p. 85). The myth replicated itself and encompassed the notion that Southern California and Chicago gangs formed alliances in their respective regions and expanded across the United States.

Reality: A few youth gangs have evolved into highly organized, entrepreneurial adult criminal organizations (Valdez, 2007). But studies in several cities, including Denver,Colorado; Cleveland and Columbus, Ohio; Detroit, Michigan; Kansas City, Missouri; Milwaukee, Wisconsin; Phoenix,Arizona; San Francisco and San Diego, California; Seattle, Washington; St. Louis, Missouri; and Las Vegas and Reno, Nevada, show that gangs are far less organized than expected (For references, see Howell, 2003, p. 79; also Bynum \& Varano, 2003; McCorkle \& Miethe, 2002; Zatz $\&$ Portillos, 2000). The "gang" label implies a high level of structure and organization for criminal conspiracy that exceeds the capacity of most street gangs. As Klein notes (2004, pp. 57-59), "Organized crime groups such as drug cartels must have strong leadership, codes of loyalty, severe sanctions for failure to abide by these codes, and a level of entrepreneurial expertise that enables them to accumulate and invest proceeds from drug sales." In contrast, "most street gangs are only loosely structured, with transient leadership and membership, easily transcended codes of loyalty, and informal rather than formal roles for the members."

Very few youth gangs meet the essential criteria for classification as "organized crime" noted above. Gangs are generally loosely organized groups that are constantly changing-consolidating, reorganizing, and splintering (Decker, Bynum, \& Weisel, 1998; Fleisher, 1998; Howell, Moore, \& Egley, 2001; Klein, 1995, 2004; Moore, 1993; Weisel, 2002).

\section{The Connected-Gangs Myth}

This myth - that small local gangs are spawned by bigcity gangs-is a key premise of the Big Gang Theory and broadcast media accounts. Local gangs that call themselves Crips and Bloods, for example, are assumed to be affiliated with parent gangs of the same names in distant cities.
Reality: This myth persists because of the similarity of their names and symbols, which is explained by mimicry or imitation. For example, although local Little League baseball teams use the name and uniform of major league baseball teams, there is no connection between local youth teams and professional baseball clubs. So it is with gangs; there rarely is any connection between local gangs and big city gangs known by the same names. The reality is that local gangs often "cut and paste" bits of Hollywood images of gangs and big-city gang lore into their local versions of gangs, forming what have come to be called "hybrid gangs" (Starbuck, Howell, \& Lindquist, 2001). They often do a poor job of copying-perhaps using the wrong colors, distorting the original gang's symbols, and so on. A youth gang in Kansas City said they were affiliated with the Chicago Folks gang, but when asked about the nature of their affiliation, they couldn't explain it. They said that they just liked to draw the Folks' pitchfork symbol (Fleisher, 1998, p. 26).

\section{The Gang-Migration Myth}

The Gang-Migration myth is that youth gangs migrate across the country to establish satellite sets. The most predominant myth is that local gangs came from somewhere else to set up a drug trafficking operation in a new location. Readers may have seen arrows superimposed on national maps to illustrate the supposed movement of gangs across the country. Law enforcement also claims there is international gang migration.

Reality: Gang migration, if it occurs, generally extends only approximately 100 miles from the city of origin, and rarely further (Maxson, 1999). Few gangs have the capacity to expand into other regions (National Alliance of Gang Investigators, 2005), and the notion of international migration of gangs has been debunked (McGuire, 2007). Some gang member migration does occur, apparently coinciding with the continuing U.S. population shift from metropolitan to suburban and rural areas, which was most pronounced during the 1980s and 1990s (Miller, 2001). Research shows that the most common reason for any migration is that the family of a gang member moves to improve the quality of life and to be near relatives and friends (Maxson, 1999). Drug market expansion applies in not more than two out of ten cases (Egley \& Ritz, 2006). Most youth gang problems are "homegrown" and gang members rather than gangs tend to migrate (Klein, 
1995, 2004). When families move, their gang-involved children usually move with them.

\section{The Gangs-Drugs-and-Violence Myth}

This myth, another product of the Big Gang Theory that imaginative gang inmates told to researchers in the late 1980s, describes violent money-making gangs that wiped out local drug dealers as they marched across the country. Thus it seemed obvious that gangs, drugs, and violence were inexorably linked. This myth was created by the gang inmates and repeated by criminologists to explain the rise in youthful firearm homicides during the late 1980s and early 1990s (Blumstein, 1995a, 1995b; Cook \& Laub, 1998; Fox, 1996). These criminologists suggested that the increasing gun violence was attributable partly to drug-trafficking gangs that grew to profit from the "crack cocaine epidemic." The gangs-drugs-violence myth was revived again last year in the broadcast media (Johnson, 2006), to help explain homicide increases.

Reality: Although youth gangs are almost invariably homegrown, their role in drug trafficking is more difficult to disentangle. Although individual members often are involved in personal drug sales, the youth gangs themselves rarely manage or control drug trafficking operations (Howell \& Decker, 1999; Howell \& Gleason, 1999). Drug trafficking is the province of organized crime syndicates and drug cartels (Gugliotta \& Leen, 1989; Leinwald, 2007). Gang member involvement at the level of street sales brings gangs into the mix, because their members very often use drugs and need to procure them. The gang collectively encourages drug use and small sales and sometimes provides protection for its drug-selling members even though the gang itself may not benefit from the sales (Valdez \& Sifaneck, 2004).

What about the violence connection? Does youth gang involvement in the drug business lead to violence that is comparable to the violence that attends strictly drug gangs? The reality is that it rarely does; youth gangrelated violence mainly emanates from inter-gang rivalries, turf protection and expansion, and interpersonal disputes or "beefs" (Braga, 2004; Howell \& Decker, 1999).

What about homicides? Studies in nine citiesBoston, Massachusetts; Baltimore, Maryland; Chicago, Illinois; Indianapolis, Indiana; Los Angeles, California; Minneapolis, Minnesota; Pittsburgh, Pennsylvania; St. Louis, Missouri; and Stockton, California-have shown that gangs account for a large number of homicides, but the correlation between gang-related homicides and drug trafficking is actually very weak (For references, see Howell, 2003 and the following studies: Braga, Kennedy, \& Tita, 2002; Cohen \& Tita, 1999; Decker \& Curry, 2003; Howell, 1999; McGarrell \& Chermak, 2003; Tita, Riley, \& Greenwood, 2003). Youth gang homicides are caused by many other factors. Researchers in most of these cities found groups of chronic violent offenders who were "locked in a self-sustaining dynamic of violence often driven by fear, 'respect' issues, and vendettas" (Braga et al., 2002, p. 283). Even when drug trafficking is a factor, fighting over drug territory is rarely an important element. An ingenious gang violence researcher, George Tita, makes a revealing observation based on his Los Angeles study, that even in situations where gangs, drugs, and homicides coincided in Los Angeles, the motivation for those homicides was much more likely to stem from an argument over quantity/quality of the drugs, payment, or robbery of a drug dealer or customer than from two groups fighting for market control (Tita et al., 2003).

\section{The All-Gangs-are-Alike Myth}

Gangs attempt to create the impression that they are at least as dangerous as the next gang. If they were not perceived to be dangerous, they would be ineffective in protecting their members.

Reality: After studying more than 1,000 Chicago gangs, the first gang researcher, Fredrick Thrasher, observed in 1927 that "no two gangs are just alike; [there is] an endless variety of forms." This conclusion has not changed (Howell et al., 2001). Police respondents describe the typical gang in their jurisdiction as a looseknit organization (45\%) with no formal structure (47\%) (Weisel, 2002, p. 33). Many current gangs are described as having a "hybrid gang culture" (Starbuck et al., 2001; see also Esbensen, Winfree, He, \& Taylor, 2001). As a general rule, the more structured gangs in larger cities with more longstanding gang problems are far more dangerous than others in less populated areas (Howell 2006a).

\section{The All-Gang-Members-are-Black-Males Myth}

This myth, mainly a product of broadcast media (Esbensen \& Tusinski, 2007), alleges that youth gang members are typically comprised of black inner-city males.

Reality: The racial and ethnic composition of gangs 
varies considerably by locality. For example, gang members are predominantly white in primarily white communities and mainly African American in predominantly African-American communities. Overall, one out of four school-aged adolescents in gangs is white and relatively similar proportions are African American (31\%), Hispanic (25\%), and of other racial and ethnic groups (20\%) (Esbensen \& Lynskey, 2001). The newest gangproblem areas (i.e., emergence within the past decade) report, on average, a larger proportion of Caucasian/ white gang members than either African Americans or Hispanics (Howell, Egley, \& Gleason, 2002). More girls also join gangs now than in the past. In fact, in younger adolescent gangs, females account for one-fourth to onehalf of the members in various locations (Esbensen \& Lynskey, 2001; Gottfredson \& Gottfredson, 2001).

\section{The Gangs-Overwhelm-Youths Myth}

One supposed gang technique for controlling members is to overpower youngsters with initiation rituals. This popular myth holds that to become a full-fledged member, without exception, youths must participate in an initiation ritual, and perhaps commit a serious violent act against a random stranger (Best \& Hutchinson, 1996).

Reality: Like many legitimate adolescent and adult clubs, most gangs do require some ceremonial type of induction to demonstrate membership, courage, and loyalty to the gang, and gang initiations often require initiates to endure a character test in what are called "beat-downs" or "jump-ins" (Vigil, 2004). But rarely are inductees required to victimize innocent members of the public. "In none of the [research] accounts do gangs demand that initiates commit crimes of random violence against non-gang members" (Best \& Hutchinson, 1996, p. 392). In sum, "the accounts of gang initiation rites promoted by contemporary legends can be regarded as melodramatic versions of press reports that routinely attribute violence to gang initiations" (p. 395). Several versions of ritual-associated myths are periodically circulated on the Internet in the form of "urban legends." 6

\section{The Youths-are-Pressured-by-Peers Myth}

A commonly held notion about gang involvement is that youths are pressured to join these organizations.

Reality: As unlikely as it may seem, many youths very much want to belong to gangs. Gangs often are at the center of appealing social action-parties, hanging out, music, dancing, drugs, and opportunities to participate in social activities with members of the opposite sex. Gang members are often looked up to by other adolescents because of their rebellious and defiant demeanor. ${ }^{7}$ Social interaction and a need for protection are the main reasons that youth give when asked why they joined a gang (Howell \& Egley, 2005b).

They want to feel safe and secure, and they want to be an integral part of the social scene. They may seek support that their own parents and families do not provide. The pressures they may feel to join the gang are usually associated with family relations and normal peer influences, or come from gang members who warn them that they may be without protection if they do not join-particularly in correctional institutions. Most youths can manage these circumstances without reprisal from other gang members (Decker \& Kempf-Leonard, 1991) but correctional situations often complicate matters. The gang-joining process is generally similar to the manner in which most of us would go about joining an organization. It is a gradual one in which a youngster typically begins hanging out with gang members at age 12 or 13 (even younger in some instances), and joins the gang between 13 and 15-typically taking from six months to a year or two from the time of initial associations (Decker \& Van Winkle, 1996; Esbensen \& Huizinga, 1993; Huff, 1996, 1998). But many associates never join.

\section{The Many-Adolescents-are-Recruited-by-Adults-to- Join-Gangs Myth}

It is widely believed that adult gang members pressure children and adolescents to join gangs. A corollary view is that adult gangs recruit youngsters to act as runners in their lucrative drug trade. Because of these concerns, a number of state anti-gang laws include enhanced penalties for recruiting children into gangs.

Reality: Prison gangs actively recruit new members through threats, force, and protection offers (Fleisher \& Decker, 2001), but street-based youth gangs rarely use strong-arm tactics (Decker et al., 1998). Moreover, very few gang studies have documented the use of juveniles in drug running. One exception has been 
documented recently in Detroit (Bynum \& Varano, 2003). Interestingly, Milwaukee's older gang members actually refused to allow juveniles to get involved in the drug trade, because of the dangers involved (Hagedorn, 1994).

\section{The Once-Kids-Join-a-Gang-They're-Pretty-Much- Lost-for-Good Myth}

Gang involvement is seen as a permanent condition; once youths join a gang, there is no turning back. The grip of the gang is said to be permanent.

Reality: Youth gang membership patterns are very transitory. Studies in numerous localities show that more than half of young gang members stay in the gang for less than a year (Gatti, Tremblay, Vitaro, \& McDuff, 2005; Hill, Lui, \& Hawkins, 2001; Peterson, Taylor, \& Esbensen, 2004; Thornberry, Krohn, Lizotte, Smith, \& Tobin, 2003). This appears to be a common pattern, but there are exceptions in some locations. Studies of gang members in several sites have revealed that they normally can leave the gang without serious consequences (Decker \& Lauritsen, 1996). Youths can dissolve their gang membership by reversing the process by which they joined, by gradually disassociating with other members. Participation in a variety of peer groups is common during the adolescent period (Warr, 2002).

\section{The Gang's-Here-for-Good Myth}

It is commonly believed that once gangs appear, they become a permanent fixture in communities. This notion seems to be based on the view that gangs select certain areas for domination-to serve their own ends.

Reality: National survey data show that in cities with populations under 50,000, gang problems regularly wax and wane (Howell \& Egley, 2005a). In areas with populations under 25,000 , only $10 \%$ of the localities reported persistent gang problems. Having a gang problem is certainly not a permanent condition in sparsely populated areas. Moreover, in these smaller areas, gang problems are, comparatively speaking, relatively minor in terms of size (e.g., number of gangs and gang members) and impact on the community. Hence the probability of permanent gang problems is far greater in the nation's large cities than in smaller cities and rural counties; although experiencing gangs forever once they appear is not by any means a certainty-even in large cities (Howell, 2006a).

\section{The Gangs-Dominate-Girls Myth}

This myth also has its origins in exaggerated images of dominating gangs, but it appears to be rooted mainly in the males' common tendency to view females in the gang as possessions, and as auxiliary participants. Male gang members have repeatedly told researchers that group sex was an initiation ritual for female gang members.

Reality: Sexual gangbanging appears to largely be a fantasy that male gang members often verbalize. Accounts given by females in gangs have largely refuted this myth in several studies (Moore \& Hagedorn, 2001). Females are increasingly participating in gangs, and although all-female gangs are still relatively rare, girls are active players in many male-dominated gangs. In 2000, $42 \%$ of all gang-problem jurisdictions in the National Youth Gang Survey reported a majority of their gangs had female members (Egley et al., 2004).

\section{The Nothing-Works-With-Gangs Myth}

Youth gang problems can be extremely intractable in large cities. In fact, gang problems remain consistently serious in our nation's largest cities (Egley et al., 2004). Viewed from this vantage point, it is easy to conclude that nothing works with gangs. This myth has most recently been promoted in a book by two prominent gang researchers, Malcolm Klein and Cheryl Maxson (2006).

Reality: However, Klein and Maxson overlooked nine programs that have proved effective with gangs or gang members (Howell, 2006b). These programs were rated using widely accepted scientific criteria, for inclusion in a national database of programs that address child and adolescent problem behaviors, including gang involvement. This database is connected to the Community Guide to Helping America's Youth, that nine Federal agencies worked together to develop in 20052006.8 Participating agencies agreed on the program rating criteria, ${ }^{9}$ and programs that qualify for inclusion in the database fall into one of the following categories: Level 1 (equivalent to "exemplary" or "model program" designation), Level 2 (equivalent to "effective"), and Level 3 (equivalent to potentially effective or "promising"). Of the nine reviewed evidence-based programs, eight were classified as Level 2, or "effective" programs, and one of 
them (the Montreal Preventive Treatment Program) was classified as an "exemplary" program (Howell, 2006b). ${ }^{10}$ One of the effective gang programs, the Chicago Gang Violence Reduction Program, showed crime reductions at the individual, gang, and community level (Spergel, 2007), contradicting the Klein and Maxson review of this particular program. ${ }^{11}$

\section{Implications for Combating Gangs}

Research suggests that to be successful over the long term in dealing with gangs, communities must take a balanced and comprehensive approach. As a first step, every community that suspects it has a gang problem should make an objective, community-wide assessment to determine whether in fact a gang problem exists and the dimensions of the problem. Without the benefit of an empirical assessment, community stakeholders run a high risk of being seriously mistaken about the nature of their gang problem (McCorkle \& Miethe, 2002). Every effort must be made in this assessment to discard preconceived notions because many of them are based on gang myths. Community resources are often committed to suppression approaches that could be used advantageously for more appropriate intervention and prevention efforts that better match the nature of the gang problem that actually exists.

To make better informed dispositions, judges and court personnel need the benefit of objective information on the scope and severity of gang problems in the community from community-wide assessments, for which an explicit protocol is available from the National Youth Gang Center (2002a).This information provides a context for interpreting the implications of court-assessed gang involvement. Gang-involved offenders should be placed within the appropriate level of a highly structured system of graduated sanctions. Youths involved in less dangerous and less entrenched gangs probably need less intensive interventions to remove them from gangs.

In more populous communities that have a serious gang problem, intervention teams should be established to provide intensive services and more restrictive sanctions for higher risk gang members. These teams, comprised of inter-agency professionals, would develop individualized treatment plans that include a schedule of graduated sanctions for non-compliance.The adjudication process, placement decisions, and treatment and sanction plans should be governed by the adjudged dangerousness and stability of the gangs in which offenders participate and the role of the subject offenders in them.

Such an intervention team can anchor a community's continuum of gang prevention, intervention, and suppression programs and strategies. A blueprint is available, called the Comprehensive Gang Prevention, Intervention, and Suppression Model. This is not a "program." Rather, it is a flexible framework that guides communities in developing and organizing a continuum of programs and strategies. Prevention programs are needed to target youths at risk of gang involvement, to reduce the number of youths that join gangs; intervention programs and strategies are needed to provide needed sanctions and services for younger youths who are actively involved in gangs to separate them from gangs; and law enforcement suppression strategies are needed to target the most violent gangs and older, criminally active gang members. Resource materials are available to assist communities in developing an action plan to implement the Comprehensive Gang Model in a way that fits each community (National Youth Gang Center, 2002b). Frequently asked questions and answers regarding gangs found online at the National Youth Gang Center, may help inform community discussions of gang-related problems. ${ }^{12}$

The results of a six-site evaluation of the Comprehensive Gang Model were mixed (Spergel, Wa, \& Sosa, 2004). Three of the communities either made fatal implementation mistakes or key agencies simply were unwilling to work together. But when it was wellimplemented in three sites, the Model effectively guided these communities (Chicago, Illinois, Mesa, Arizona, and Riverside, California) in developing services and strategies that contributed to reductions in both gang violence (in three sites) and drug-related offenses (in two sites). At the successful sites, a key factor was length of time in the program. When youths were in the program for two or more years, there were fewer arrests for all types of offenses. In general, arrest reductions were greater among older youths and females than among younger youths and males. General deterrence effects (at the project area level) were not as strong as the program effects for individual youths; nevertheless, these three sites were somewhat successful in integrating police suppression with service-oriented strategies. In sum, the evaluation 
indicates that, when properly implemented, a combination of prevention, intervention, and suppression strategies was successful in reducing the gang problem.

Because of space limitations, only one example each of effective prevention, intervention, and suppression programs that communities might consider for inclusion in their own continuum is provided here. For prevention purposes, the Montreal Preventive Treatment Program is an interesting option because it was not intended to prevent gang involvement. Rather, it was designed to prevent antisocial behavior among boys ages 7 to 9 of low socioeconomic status who had previously displayed disruptive problem behavior in kindergarten (Tremblay, Masse, Pagani, \& Vitaro, 1996). This program demonstrated that a combination of parent training and childhood skills development can steer children away from gangs. An evaluation of the program showed both short- and long-term gains, including less delinquency, less substance use, and less gang involvement at age 15 (Tremblay et al., 1996).

As noted above, the Chicago Gang Violence Reduction Program proved to be an effective intervention program (Spergel, 2007). It targeted mainly older members (ages 17 to 24) of two of the area's most violent Hispanic gangs. Although the outcomes for the Little Village project are mixed, the results are consistent for violent crimes across analyses, at the individual, group (gang), and community levels (especially in the views of residents). Interestingly, the evaluation suggested that a youth outreach (or social intervention) strategy may be more effective in reducing the violent behavior of the younger, less violent gang youth, and that a combined youth outreach and police suppression strategy might be more effective with the older, more criminally active and violent gang youth, particularly with respect to drug-related crimes.

Targeted gang suppression has shown some success. A three-pronged suppression strategy of: (a) selective incarceration of the most violent and repeat older gang offenders in the most violent gangs; (b) enforcement of probation controls (graduated sanctions and intensive supervision) on younger, less violent gang offenders; and (c) arrests of gang leaders in "hot spots" of gang activity proved somewhat effective in the Tri-Agency Resource Gang Enforcement Team (TARGET) program in Orange County, California (Kent, Donaldson, Wyrick, \& Smith, 2000).

\section{Conclusion}

We do not underestimate the severity of gang problems, which are extremely formidable in many communities, particularly in cities with populations of 100,000 or more. But youth gang problems are often difficult to assess, and gangs are often shrouded in myths, which can lead to ineffective community responses. For example, if it is believed that local gangs migrated from distant cities such as Los Angeles, officials may assume that the newly arrived gang members can be driven out. If they are long-term residents of the city, however, this approach is unlikely to work. To be successful in combating gangs, communities must distinguish youth gangs from other groups that also are called "gangs" such as troublesome youth groups, prison gangs, drug gangs, adult criminal organizations, and organized crime.

Many of the myths are promulgated by the gangs themselves in order to enhance their status and aura of danger. In part because of these myths, community stakeholders often struggle to determine the appropriate response to gang problems. A comprehensive, balanced approach of prevention, intervention, and suppression strategies and programs is most likely to be successful. For maximum impact, it must be based on an objective assessment of the local gang problem.

$$
\begin{gathered}
\text { A U T H O R ' S } \\
\text { A D D R E S S : } \\
\text { James C. Howell, Ph.D. } \\
\text { Senior Research Associate } \\
\text { National Youth Gang Center } \\
\text { Institute for Intergovernmental Research } \\
\text { P.O. Box } 12729 \\
\text { Tallahassee, FL } 32317 \\
\text { E-mail: bhowell@iir.com }
\end{gathered}
$$




\section{REFERENCES}

Bernard, T. (1992). The cycle of juvenile justice. New York: Oxford University.

Best, J., \& Hutchinson, M. M. (1996). The gang initiation rite as a motif in contemporary crime discourse. Justice Quarterly, 13, 383-404.

Blumstein,A. (1995a).Violence by young people: Why the deadly nexus? National Institute of Justice Journal, August, 1-9.

Blumstein, A. (1995b). Youth violence, guns, and the illicit-drug industry. Journal of Criminal Law and Criminology, 86, 10-36.

Braga, A. A. (2004). Gun violence among serious young offenders. Problem-oriented guides for police. Problemspecific guides series. Guide No. 23. Washington, DC: Office of Community Oriented Policing Services.

Braga,A.A., Kennedy, D. M., \& Tita, G. E. (2002). New approaches to the strategic prevention of gang and group-involved violence. In C. R.Huff (Ed.), Gangs in America III (pp. 271-285).Thousand Oaks, CA: Sage Publications.

Bynum, T. S., \& Varano, S. P. (2003). The anti-gang initiative in Detroit: An aggressive enforcement approach to gangs. In S. H. Decker (Ed.), Policing gangs and youth violence (pp. 214-238). Belmont, CA:Wadsworth/Thompson Learning.

Cohen,J.,\&Tita, G.(1999). Spatial diffusion in homicide: Exploring a general method of detecting spatial diffusion processes. Journal of Quantitative Criminology, 15(4), 451-493.

Cook, P. J., \& Laub, J. H. (1998). The unprecedented epidemic of youth violence. In M.Tonry \& M.H. Moore (Eds.), Youth violence (pp. 27-64). Chicago: University of Chicago Press.

Decker, S. H., Bynum, T., \& Weisel, D. (1998). A tale of two cities: Gangs as organized crime groups.Justice Quarterly, 15, 395-423.

Decker, S. H., \& Curry, G. D. (2003). Suppression without prevention, prevention without suppression. In S. H. Decker (Ed.), Policing Gangs and Youth Violence (pp. 191-213). Belmont, CA:Wadsworth/Thompson Learning.

Decker, S. H., \& Kempf-Leonard, K. (1991). Constructing gangs: The social definition of youth activities. Criminal Justice Policy Review, 5, 271-291.

Decker, S. H., \& Lauritsen, J. L. (1996). Breaking the bonds of membership: Leaving the gang. In C. R. Huff (Ed.), Gangs in America (pp. 103-122). Thousand Oaks, CA: Sage.

Decker, S. H., \& Van Winkle, B. (1996). Life in the gang: Family, friends, and violence. New York: Cambridge University Press.

Eddy, P., Sabogal, H., \& Walden, S. (1988). The cocaine wars. New York:W.W. Norton.
Egley,A.Jr., Howell, J. C., \& Major,A. K. (2004). Recent patterns of gang problems in the United States: Results from the 1996-2002 National Youth Gang Survey. In F.A. Esbensen, S. G.Tibbetts, \& L. Gaines (Eds.), American youth gangs at the millennium (pp. 90-108). Long Grove, IL:Waveland Press, Inc.

Egley,A., Jr., \& Ritz, C.E. (2006).Highlights of the 2004 National Youth Gang Survey. OJJDP Fact Sheet (\#2006-1). Washington, DC: U.S. Department of Justice, Office of Juvenile Justice and Delinquency Prevention. Available online: http://www.iir. com/NYGC.

Esbensen,F, \& Huizinga,D.(1993).Gangs,drugs, and delinquency in a survey of urban youth. Criminology, 31, 565-589.

Esbensen, F., \& Lynskey, D. P. (2001). Youth gang members in a school survey. In M. W. Klein, H. Kerner, C. L. Maxson, \& E. Weitekampf (Eds.), The Eurogang Paradox: Street gangs and youth groups in the U.S. and Europe. Amsterdam: Kluwer Academic Publishers.

Esbensen, F, \& Tusinski, K. (2007). Youth gangs in the print media.Journal of Criminal Justice and Popular Culture, 14, 21-28.

Esbensen, F., Winfree, L. T., He, N., \& Taylor, T. J. (2001). Youth gangs and definitional issues: When is a gang a gang, and why does it matter? Crime and Delinquency, 47(1), 105-130.

Felson, M. (2006). The street gang strategy. In M. Felson, Crime and nature (pp. 305-324). Thousand Oaks, CA: Sage Publications.

Fernandez, M. E. (1998, Nov. 15). An urban myth sees the light again. The Washington Post, p. B2.

Fleisher, M. S. (1998). Dead end kids: Gang girls and the boys they know. Madison, WI: University of Wisconsin.

Fleisher, M. S., \& Decker, S. (2001).An overview of the challenge of prison gangs. Corrections Management Quarterly, 5(1), 1-9.

Fox, J.A. (1996). Trends in juvenile violence: A Report to the United States Attorney General on current and future rates of juvenile offending. Washington, DC: Bureau of Justice Statistics.

Gatti, U., Tremblay, R. E., Vitaro, F., \& McDuff, P. (2005). Youth gangs, delinquency and drug use:A test of selection, facilitation, and enhancement hypotheses. Journal of Child Psychology and Psychiatry, 46(11), 1178-1190.

Gottfredson, G. D., \& Gottfredson, D. C. (2001). Gang problems and gang programs in a national sample of schools. Ellicott City, MD: Gottfredson Associates. 


\section{REFERENCES}

Gugliotta, G., \& Leen, J. (1989). Kings of cocaine. New York: Simon \& Schuster.

Hagedorn, J. M. (1994). Homeboys, dope fiends, legits, and new jacks. Criminology, 32(2), 197-217.

Hartman, D. A., \& Golub, A. (1999). The social construction of the crack epidemic in the print media.Journal of Psychoactive Drugs, 31(4), 423-433.

Hill, K. G., Lui, C., \& Hawkins, J. D. (2001). Early precursors of gang membership: A study of Seattle youth. Juvenile Justice Bulletin. Washington, DC: U.S. Department of Justice, Office of Juvenile Justice and Delinquency Prevention.

Howell, J. C. (1998). Youth gangs:An overview. Juvenile Justice Bulletin.Youth Gang Series. Washington, DC: U.S. Department of Justice, Office of Juvenile Justice and Delinquency Prevention.

Howell, J. C. (1999). Youth gang homicides:A literature review. Crime and Delinquency, 45(2), 208-241.

Howell, J. C. (2003). Preventing and reducing juvenile delinquency: A comprebensive framework. Thousand Oaks, CA: Sage Publications.

Howell, J. C. (2006a). The impact of gangs on communities. NYGC Bulletin No. 2. Tallahassee, FL: National Youth Gang Center. Available online: http://www.iir.com/NYGC.

Howell, J. C. (2006b). Lessons learned from the "Spergel Model" and other gang program evaluations. Paper presented January 20, 2006 at the Spergel Festschrift Symposium, University of Chicago, Chicago, IL.

Howell,J. C., \& Decker, S. H. (1999).The youth gangs, drugs, and violence connection. Juvenile Justice Bulletin, Youth Gang Series. Washington, DC: U.S. Department of Justice, Office of Juvenile Justice and Delinquency Prevention. Available online: http://www.iir.com/NYGC.

Howell, J. C., \& Egley, A., Jr. (2005a). Gangs in small towns and rural counties. NYGC Bulletin, No.1. Tallahassee, FL: National Youth Gang Center.

Howell, J. C., \& Egley, A., Jr. (2005b). Moving risk factors into developmental theories of gang membership. Youth Violence and Juvenile Justice, 3(4), 334-354.

Howell, J. C., Egley, A., Jr., \& Gleason, D. K. (2002). Modern day youth gangs. Juvenile Justice Bulletin, Youth Gang Series. Washington, DC: U.S. Department of Justice, Office of Juvenile Justice and Delinquency Prevention.
Howell,J.C., \& Gleason,D.K.(1999).Youth gang drug trafficking. Juvenile Justice Bulletin, Youth Gang Series. Washington, DC: U.S. Department of Justice, Office of Juvenile Justice and Delinquency Prevention.

Howell, J. C., Moore, J. P., \& Egley, A. Jr. (2001). The changing boundaries of youth gangs. In C. R. Huff (Ed.), Gangs in America III (pp. 3-18). Thousand Oaks, CA: Sage Publications.

Huff, C. R. (1996). The criminal behavior of gang members and non-gang at-risk youth. In C. R. Huff (Ed.), Gangs in America (2nd ed., pp. 75-102).Thousand Oaks, CA: Sage Publications.

Huff, C. R. (1998). Comparing the criminal behavior of youth gangs and at-risk youth. Research in Brief. Washington, DC: National Institute of Justice.

Johnson, K. (2006, July 13). Police tie jump in crime to juveniles: Gangs, guns, add up to increased violence. USA Today, pp.A1,A3.

Kent, D. R., Donaldson, S. I., Wyrick, P. A., \& Smith, P. J. (2000). Evaluating criminal justice programs designed to reduce crime by targeting repeat gang offenders. Evaluation and Program Planning, 23, 115-124.

Klein, M. W. (1995). The American street gang. New York: Oxford University Press.

Klein, M.W. (2004). Gang cop: The words and ways of Officer Paco Domingo. Walnut Creek, CA:Alta Mira Press, pp. 57-59.

Klein, M.W., \& Maxson, C. L. (2006). Street gang patterns and policies. New York: Oxford University Press.

Leinwald,D.(2007, March 1).DEA busts ring accused of sending tons of drugs to US. USA Today, p.A11.

Maxson, C. L. (1999). Street gang members on the move: The role of migration in the proliferation of street gangs in the U.S. Juvenile Justice Bulletin, Youth Gang Series. Washington, DC: U.S. Department of Justice, Office of Juvenile Justice and Delinquency Prevention.

McCorkle, R. C., \& Miethe, T. D. (2002). Panic: The social construction of the street gang problem. Upper Saddle River, NJ: Prentice-Hall.

McGarrell, E. F., \& Chermak, S. (2003). Problem solving to reduce gangs and drug-related violence in Indianapolis. In S. H. Decker (Ed.), Policing gangs and youth violence (pp. 77-101). Belmont, CA:Wadsworth/Thompson Learning.

McGuire, C. (2007). Working paper on Central American youth gangs in the Washington D.C.area. Washington,DC:Washington Office on Latin America. 


\section{REFERENCES}

Miller,W. B. (2001). The growth of youth gang problems in the United States: 1970-1998. Washington, DC: U.S. Department of Justice, Office of Juvenile Justice and Delinquency Prevention. Available online: http://www.iir.com/NYGC.

Moore, J.W. (1993). Gangs, drugs, and violence. In S. Cummings \& D.J. Monti, (Eds.), Gangs (pp. 27-46). Albany, NY: State University of New York Press.

Moore, J. W., \& Hagedorn, J. M. (2001). Female gangs: A focus on research. Juvenile Justice Bulletin, Youth Gang Series. Washington, DC: U.S. Department of Justice, Office of Juvenile Justice and Delinquency Prevention.

National Alliance of Gang Investigators. (2005). National gang threat assessment: 2005. Washington, DC: Bureau of Justice Assistance, U.S. Department of Justice.

National Youth Gang Center. (2002a). OJJDP Comprehensive Gang Model: Assessing Your Community's Youth Gang Problem. Washington, DC: Office of Juvenile Justice and Delinquency Prevention.

National Youth Gang Center. (2002b). OJJDP Comprehensive Gang Model: Planning for Implementation. Washington, DC: Office of Juvenile Justice and Delinquency Prevention.

Peterson,D.,Taylor,T.J.,\& Esbensen,F.(2004).Gang membership and violent victimization. Justice Quarterly, 21(4), 793-815.

Reeves,J.L. \& Campbell,R.(1994).Cracked coverage:Television news, the anti-cocaine crusade, and the Reagan legacy. Durham, NC: Duke University Press.

Skolnick, J. H. (1989). Gang organization and migration. Sacramento, CA: Office of the Attorney General of the State of California.

Skolnick,J.H.(1990).The social structure of street drug dealing. American Journal of Police, 9, 1-41.

Spergel, I.A. (2007). Reducing youth gang violence:The Little Village Gang Project in Chicago. Lanham, MD:AltaMira Press.

Spergel, I.A.,Wa, K. M., \& Sosa, R.V. (2004). The comprebensive, community-wide gang program model: Success and failure. Chicago: School of Social Service Administration, University of Chicago.

Starbuck, D., Howell, J. C., \& Lindquist, D. J. (2001). Into the millennium: Hybrids and other modern gangs. Juvenile Justice Bulletin, Youth Gang Series. Washington, DC: U.S. Department of Justice, Office of Juvenile Justice and Delinquency Prevention.Available online: http://www.iir.com/NYGC.
Thornberry, T. P., Krohn, M. D., Lizotte, A. J., Smith, C. A., \& Tobin, K. (2003). Gangs and delinquency in developmental perspective. New York: Cambridge University Press.

Tita, G., Riley, K. J., Ridgeway, G., Grammich, C., Abrahamse, A., \& Greenwood, P. W. (2003). Reducing gun violence: Results from an intervention in East Los Angeles. Santa Monica, CA: RAND Corporation.

Tremblay, R. E., Masse, L., Pagani, L., \& Vitaro, F. (1996). From childhood physical aggression to adolescent maladjustment: The Montreal Prevention Experiment. In R. D. Peters \& R. J. McMahon (Eds.), Preventing childbood disorders, substance abuse, and delinquency (pp. 268-298). Thousand Oaks, CA: Sage Publications.

Valdez, A. (2007). Gangs: A guide to understanding street gangs (5th ed.). San Clemente, CA: LawTech Publishing Co.

Valdez,A., \& Sifaneck, S. J. (2004). "Getting high and getting by": Dimensions of drug selling behaviors among Mexican gang members in south Texas. Journal of Research in Crime and Delinquency, 41(1), 82-105.

Vigil, J. D. (2004). Street baptism: Chicano gang initiation. In F. A. Esbensen, S. G. Tibbetts, \& L. Gaines (Eds.), American youth gangs at the millennium (pp. 218-228). Long Grove, IL: Waveland Press.

Warr, M. (2002). Companions in crime: The social aspects of criminal conduct. New York: Cambridge University Press.

Weisel, D. L. (2002). The evolution of street gangs: An examination of form and variation. In W. Reed \& S. Decker (Eds.), Responding to gangs: Evaluation and research (pp. 25-65). Washington, DC: U.S. Department of Justice, National Institute of Justice.

Wiist, W. H., Jackson, R. H., \& Jackson, K. W. (1996). Peer and community leader education to prevent youth violence. American Journal of Preventive Medicine, Suppl., 12(5), 60.

Zatz, M. S., \& Portillos, E. L. (2000). Voices from the barrio: Chicano/a gangs, families, and communities. Criminology, 38(2), 369-401. 


\section{END NOTES}

1 The following are widely accepted criteria for classifying groups as "youth gangs" (or street gangs):

- The group consists of three or more young persons, generally ages 12 to 24 .

- Members share some sense of identity, a name, and symbols such as colors, graffiti, clothes, language, and hand signs.

- The group shows some permanence, a degree of organization, and a street presence.

- The group is involved in delinquent or criminal activity beyond a normal level.

2 Politicians, especially legislators, also exaggerate the realities of gangs but are not considered here because of space limitations.

3 It is not our intent to downplay the seriousness of gang problems in many cities in the United States. Gangs are very real and dangerous in many urban localities, and their contribution to the community-wide volume of violence is substantial (Howell, 2006a).

4 Technically speaking, myths refer to beliefs that are strongly held and convenient to believe but are based on little actual information; they are not necessarily false (Bernard, 1992, p. 11). Beliefs that are unequivocally false are properly labeled fallacies. Although useful, such a clear-cut distinction often cannot be made in reference to gangs because, depending on how they are defined, at least one exception may be found to every myth, thus the more inclusive term is used herein.

5 The crack cocaine epidemic is also largely a myth Surprisingly, no one has presented convincing empirical evidence that a nationwide crack cocaine epidemic in fact occurred. See Reeves \& Campbell (1994); also Hartman \& Golub (1999).

6 See http://www.snopes.com/crime/gangs/gangs.asp. For example, "flickered headlights" refers to a legend that gang members drive after dark with their headlights turned off in order to choose victims. According to this myth, if an approaching motorist flashes his or her headlights at the gang members' car (presumably in a friendly attempt to alert the driver that the lights are off), the gangsters must chase down and kill the motorist (Fernandez, 1998).

7 In a survey of Houston middle-school students, the classmates that they looked up to as peer leaders did not have the qualities one might expect. One in four had beaten or punched another person and nearly two in ten had been in a gang fight (Wiist, Jackson, \& Jackson, 1996).
8 This database can be accessed at http://helpingamericas youth.gov. One of the effective gang programs, Gang Resistance Education and Training, appears instead in the National Youth Gang Center's Strategic Planning Tool (http://www.iir.com/nygc/tool).

9 The overall rating is derived from four summary dimensions of program effectiveness: the conceptual framework of the program, program fidelity, strength of the evaluation design, and the empirical evidence demonstrating the prevention or reduction of problem behaviors.

10 Two of the effective programs are supported by a common study. Three studies support the effectiveness of the Comprehensive Gang Model. One of these is the evaluation of the Gang Violence Reduction Program, which is the sole evaluation of its effectiveness.

11 Klein and Maxson also overlooked programs that prevent or reduce gang involvement by serving high-risk youths rather than specifically targeting gang members. Three of the effective programs are in this category.

12 See the National Youth Gang Center's Web site at http:// www.iir.com/nygc/faq.htm. 